\title{
Self-incompatibility alleles in Esatern European and Asian almond (Prunus dulcis) genotypes: a preliminary study
}

\author{
Szikriszt, B. ${ }^{1}$, Ercisli, S. ${ }^{2}$, Hegedüs, A. ${ }^{1}$ \& Halász, J. ${ }^{1}$ \\ ${ }^{I}$ Department of Genetics and Plant Breeding, Corvinus University of Budapest, \\ Ménesi út 44, 1118, Budapest, Hungary \\ ${ }^{2}$ Department of Horticulture, Ataturk University, 25240, Erzurum, Turkey; \\ E-mail: julia.halasz@uni-corvinus.hu
}

\begin{abstract}
Summary: Almond [Prunus dulcis (Mill.) D. A. Webb.] as one of the oldest domesticated plants is thought to have originated in central Asia. Gametophytic self-incompatibility of almond is controlled by the highly polymorphic $S$-locus. The $S$-locus encodes for an $S$-ribonuclease ( $S$-RNase) protein in the pistils, which degrades RNA in self-pollen tubes and hence stops their growing. This study was carried out to detect $S$-RNase allelic variants in Hungarian and Eastern European almond cultivars and Turkish wild growing seedlings, and characterize their $S$-allele pool. Five new alleles were identified, $S_{31 \mathrm{H}}, S_{36}-S_{39}$ in Eastern European local cultivars. The village Bademli and Akdamar island are two distinct places of almond natural occurrence in Turkey. Trees growing wild around Bademli city showed greater genetic diversity than those originated on Akdamar island. Many of the previously described 45 S-RNase alleles have been also detected in these regions. Homology searches revealed that Turkish almonds carried some $P$. webbii alleles indicating hybridization between the two cultivars and massive introgression events. Our results supply long-awaited information on almond $S$-allele diversity from regions between the main cultivation centres and the centre of origin of this species; and are discussed from the aspect of methodological developments and evolution of the cultivated almond.
\end{abstract}

Key words: self-in incompatibility, almond

\section{Introduction}

Almond [Prunus dulcis (Mill.) D.A. Webb. syn. P. amygdalus Batsch] is a member of Rosaceae familiy, Prunoideae subfamily. The Rosaceae family is one of the most important plant families in the temperate zone. This family includes economically important species (e.g. apple, apricot, plum, sweet and sour cherries, almond, strawberry and rose). Almond is commercially grown worldwide for its nuts. The putative origin of almond is in the arid mountainous regions of Central Asia (Grassely, 1976; Arús et al., 2009). Several wild species grow in the areas ranging from Tianshan through Afghanistan into Iran and Iraq (Grasselly, 1976; Kester \& Gradziel, 1996).

Almond shows gametophytic self-incompatibility (de Nettancourt, 2001), which is governed by the highly polymorphic, multiallelic $S$-locus. In pistils, the $S$-locus encodes for an $S$-ribonuclease ( $S$-RNase) enzyme, which degrades RNA in self-pollen tubes and stops their growing (McClure et al., 1989).

Almond is a typically outbreeding species, which has dramatic consequences on the genetic diversity of both wild growing and cultivated accessions (Szikriszt et al., 2011), similarly to other fruit species (Halász et al., 2011; Hegedüs et al., 2011). The $S$-genotypes have been identified for many USA, Spanish, Italian and French almond cultivars (López et al., 2006).
Cross-incompatibility, that means the mutual failure in the fruit set, is a well-known phenomenon in almond. Until now, more than forty self-incompatibility (SI) RNase alleles have been identified (López et al., 2006; Ortega et al, 2006; Boskovic et al., 2007; Halász et al., 2008, 2010; Kodad et al, 2008). One allele, $S_{\mathrm{f}}$, allows for self-compatibility in its inactive form, while its active form is functional (Fernández i Martí et al., 2010).

The application of DNA-based molecular markers allows for the early selection of the common $S$-alleles (Martinez-Gómez et al., 2007; Szikriszt et al., 2011). Rapid and reliable $S$-genotyping protocols were reported based on the PCR amplification of the first and the second intron regions in the S-RNase gene using degenerate primers and fragment size determination (Ortega et al., 2005). This work is the first information from a comprehensive study to determine the $S$-genotype of some Eastern European almond cultivars and some Turkish wild growing seedlings to characterize their $S$-allele pool.

\section{Materials and methods}

\section{Plant materials}

A total of 19 Eastern European and 70 Turkish almond accessions were used in the experiments including 39 


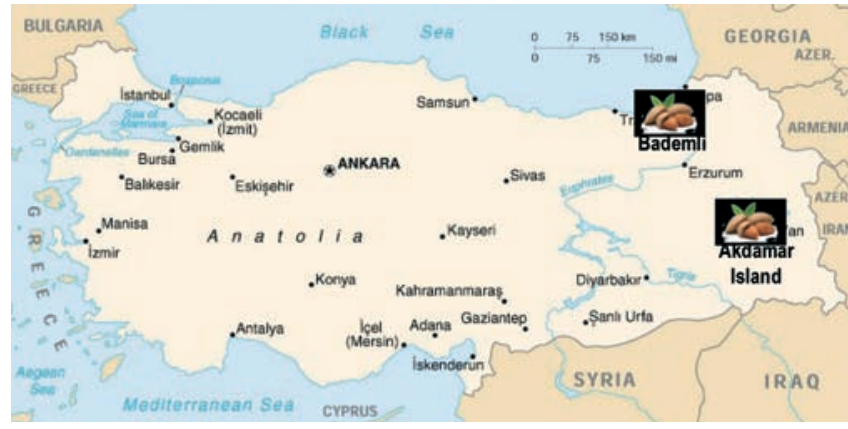

Figure 1. Map of Turkey, the origin of Turkish almond accessions (Bademli and Akdamar Island) are signed with small almond symbols

sampled trees growing wild on the Akdamar Island and 31 trees occurring around the village Bademli (Figure 1). The local Hungarian cultivars were obtained from the orchard of the Corvinus University of Budapest, Department of Genetics and Plant Breeding in Szigetcsép, Hungary.

\section{DNA extraction and genomic PCR with consensus primers}

Genomic DNA was extracted from fully expanded young leaves using the DNeasy Plant Mini Kit (Qiagen, Hilden, Germany). DNA concentration and purification parameters were measured using a NanoDrop ND-1000 Spectrophotometer (Bio-Science, Budapest, Hungary).

PCR was conducted according to Sutherland et al. (2004) using the consensus degenerate primer pairs of the EMPC2consFD and EM-PC3consRD for the amplification of the second intron region of the $S$-RNase gene. To amplify the first intron of the $S$-RNase gene, the fluorescently labelled (6FAM) PaConsI-F primer (Sonneveld et al., 2003) was used in a combination with the EM-PC1consRD primer (Ortega et al., 2005). To identify the $S_{31}$-allele, an allele-specific primer pair was used according to Halász et al. (2008).

Approximately 20-80 ng of genomic DNA was used for PCR amplification in a $25 \mu$ reaction volume, containing $10 \times$ DreamTaq $^{\text {TM }}$ Green Buffer (Fermentas, Szeged, Hungary) which contains $\mathrm{KCl}$ and $\left(\mathrm{NH}_{4}\right)_{2} \mathrm{SO}_{4}$ at a ratio optimized for robust performance of DreamTaq ${ }^{\mathrm{TM}}$ DNA Polymerase in PCR with final concentrations of $4,5 \mathrm{mM} \mathrm{MgCl} 2,0.2 \mathrm{mM}$ of dNTPs $0.2 \mu \mathrm{M}$ of the adequate primers and $0.06 \mathrm{U}$ of DreamTaq DNA polymerase (Fermentas). PCR was carried out in a PTC 200 Thermocycler (MJ Research, Budapest, Hungary) according to Sonneveld et al. (2003).

The second intron PCR products were separated by electrophoresis in 1,2\% TAE or TBE agarose gels for $2 \mathrm{~h}$ at $100 \mathrm{~V}$ and DNA bands were visualized by the ethidium bromide staining. Fragment lengths were estimated by comparison with the $1 \mathrm{~kb}$ DNA ladder (Promega, Madison, USA). To determine the exact size of the $S$-RNase first intron region fragments under $500 \mathrm{bp}$, the fluorescently labelled products were run in an automated sequencer ABI PRISM 3100 Genetic Analyzer (Applied Biosystems, Budapest, Hungary).

\section{DNA sequencing and sequence analysis of genomic PCR products}

PCR fragments were purified from agarose gel with EZ10 Spin Column DNA Gel Extraction Kit (Bio Basic Incl., Biocenter, Szeged, Hungary) and cloned into a pGEM-T Easy (Promega, Bio-Science, Budapest, Hungary) or pTz57R/T (Fermentas, Biocenter, Szeged, Hungary) plasmid vectors. The ligated vectors were transformed into DH5 $\alpha$ or XLB1 competent $E$. coli cells, prepared with Z-Competent $E$. coli Transformation Kit (Zymo Research Corp., Biocenter, Szeged, Hungary).

Plasmid DNA was isolated with the E.Z.N.A. Plasmid Miniprep Kit I. (Omega Bio-tek Incl., USA) and sequenced in an automated sequencer, ABI PRISM 3100 Genetic Analyzer (Applied Biosystems, Budapest, Hungary). For each fragment, the nucleotid sequences of two clones were determined in both directions with sequencing primer M13. DNA and deduced amino acid sequences were compared using BLASTN and TBLASTN at NCBI and CLUSTAL W program (Thompson et al., 1994) and the aligned sequences were edited with BioEdit v. 7.0.9.0.

\section{Results and discussion}

The consensus primers for the first and the second introns of the $S$-RNase gene was used for the $S$-genotype determination of all samples, and the sizes and sequences of the PCR products were compared with those previously published (Ortega et al., 2005; Boskovic et al., 2007; Kodad et al., 2008; Halász et al., 2008, 2010). To confirm the $S$-genotypes, fluorescently labelled PCR products of the first intron fragments were sized on automated sequencer.

From a range of the Eastern European almond cultivars, landraces and hybrids, five new alleles were identified: $S_{31 \mathrm{H}}$-allele (in cultivars 'Tétényi bötermö' and 'Szigetcsépi 55 (3/9)' from Hungary, 'Eriane (4/9)' and 'Eriane (4/11)' from France, and 'Moldavskyi 812' from Moldavia), $S_{36}$ (in samples 'Szigetcsépi 92' and 'Óriáskagyló (4/4)' from Hungary and 'Vinoslivyi', 'Nikitskyi 707', 'Nikitskyi 3576', 'Nikitskyi 2240' from Ukraine), $S_{37}$ (in samples 'Óriáskagyló (4/4)' from Hungary and 'Nikitskyi 707', 'Nikitskyi 3576', 'Nikitskyi 2240' from Ukraine), $S_{38}$ (in sample 'Szigetcsépi 55 (3/9)' from Hungary and $S_{39}$ (in samples 'Marie Dupuy' from France and 'Pozdnyi' from Ukraine) (Halász et al., 2010a). Genomic DNA sequences from SP (signal peptide) to $\mathrm{C} 1$ and from $\mathrm{C} 2$ to $\mathrm{C} 3$ regions were obtained for $S_{36}-S_{38}$ alleles, while for $S_{39}$, the DNA sequence was determined from SP to C1. All sequences were deposited in the NCBI Database under the accession numbers EU448294 and FJ529211-FJ529214. Two novel cross-incompatibility groups have been also proposed.

The regions of Bademli and Akdamar Island are two distinct places of almond natural occurrence in Turkey. Figure 2 and Figure 3 show the second intron PCR analysis of the investigated Turkish almonds. 


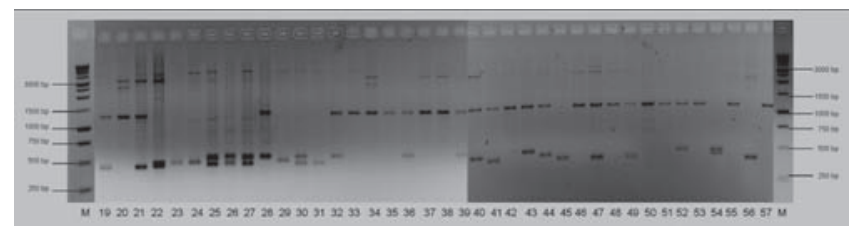

Figure 2. S-PCR analysis of 39 Turkish almond accessions from Akdamar Island, Turkey, conducted using the EMPC2-consFD and EMPC3-consRD. M: 1kb marker (Promega), 19-57: almond accessions.

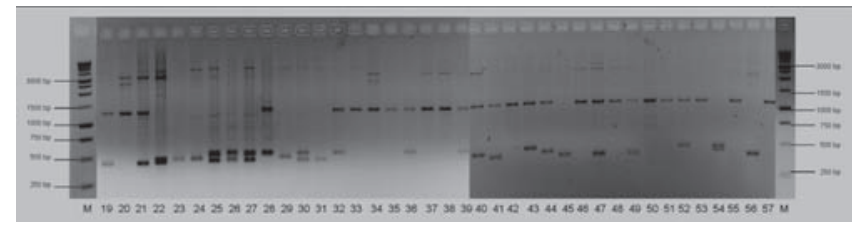

Figure 3. S-PCR analysis of 31 Turkish almond accessions from the village Bademli, Turkey, conducted using the EMPC2-consFD and EMPC3consRD. M: $1 \mathrm{~kb}$ marker (Promega), 1-31 the almond accessions.

Trees growing wild around Bademli village in Turkey showed greater genetic diversity than those originated on the Akdamar Island (located in lake Van). The two regions locate approx. $300 \mathrm{~km}$ apart. The Akdamar germplasm showed relatively few $S$-alleles presenting only a limited number of genotypes. In conclusion, many trees had identical genotypes, which might be associated with the geographical isolation of the germplasm. Some of the previously described $45 S$-RNase alleles have been also detected in these regions. More interestingly, homology searches revealed that Turkish almonds carried some $P$. webbii alleles indicating hybridization between the two cultivars and massive introgression events.

The most important concliusion of our study is that the exclusive application of the consensus PCR primers amplifying the first and second intron regions was not suitable to the reliable discrimination of the $S$-RNase alleles in a germplasm of great genetic diversity. Since several alleles from other species like $P$. webbii also occurred and some of those alleles may have similar intron lengths as $P$. dulcis S-RNases, the identification of the alleles seems to be challenging. Therefore, new strategies (allele-specific primers) will be inevitable to improve reliability in such cases.

The great genetic diversity is due to the fact that selfcompatible accessions (at least seedlings carrying the $S_{\mathrm{f}}$ ) were not found in the Hungarian and Turkish germplasm. Self-compatibility in almond is a relatively new trait of limited occurrence and hence it has not been enough time to operate for inducing genetic erosion like in apricot (Halász et al., 2010b). Interestingly, the genetic constitution of the almond germplasm seemed to be quite different according to the regions investigated and the geographic isolation was clarified to have strong effects on genetic variability. Our results supply long-awaited information on almond $S$-allele diversity from regions between the main cultivation centres (the Mediterranean Europe and California) and the centre of origin of this species.

\section{Acknowledgements}

This work was funded by the PD78124 project and also supported by the János Bolyai Research Scholarship of the Hungarian Academy of Sciences.

\section{References}

Arús, P., Gradziel, T., Oliveira, M. M. \& Tao, R. (2009): Genomics of almond. [In: Folta, K. M., Gardiner, S. E. (eds.), Genetics and Genomics of Rosaceae], Vol. 6. Springer, New York, pp. 187-219.

Boskovic, R., Tobutt, K. R., Ortega, E., Sutherland, B. G. \& Godini, A. (2007): Self-(in)compatibility of the almonds $P$. dulcis and $P$. webbii: detection and cloning of 'wild-type $S_{\mathrm{f}}$ ' and new self-compatibility alleles encoding inactive $S$-RNases. Mol. Genet. Genom., 278: 665-676.

de Nettancourt, D. (2001): Incompatibility and Incongruity in Wild and Cultivated Plants (2nd ed.). Springer-Verlag, New York.

Fernández i Martí, A., Hanada, T., Alonso, J.M., Yamane, H., Tao, R. \& Socias i Company, R. (2010): The almond $S_{f}$ haplotype shows a double expression despites its comprehensive genetic identity. Sci. Hortic.-Amsterdam, 125: 685-691.

Grasselly, C. (1976): Origine et évolution de l'amandier cultivé. (Origin and evolution of cultivated almond.) Opt. Méditerr., 32: 45-50.

Halász, J., Fodor, Á., Hegedús, A. \& Pedryc, A. (2008): Identification of a new self-incompatibility allele $\left(S_{31}\right)$ in a Hungarian almond cultivar and its reliable detection. Sci. Hortic.-Amsterdam, 116: 448-451.

Halász, J., Fodor, Á., Pedryc, A. \& Hegedús, A. (2010a): $S$-genotyping of Eastern European almond cultivars: identification and characterization of new $\left(S_{36}-S_{39}\right)$ self-incompatibility ribonuclease alleles. Plant Breeding, 129: 227-232.

Halász, J., Hegedűs, A., György, Z., Pállinger, É. \& Tóth, M. (2011): $S$-genotyping of old apple cultivars from the Carpathian Basin: methodological, breeding and evolutionary aspects. Tree Genet. Genomes, 7: 1135-1145.

Halász, J., Pedryc, A., Ercisli, S., Yilmaz, K. U. \& Hegedüs, A. (2010b): $S$-genotyping supports the genetic relationships between Turkish and Hungarian apricot germplasm. J. Amer. Soc. Hort. Sci., 135: 410-417.

Hegedüs, A., Lénárt, J. \& Halász, J. (2011): Review of sexual incompatibility in tree fruit species: molecular interactions and evolutionary dynamics. Biol. Plantarum, 56: 201-209.

Kester, D. E. \& Gradziel, T. M. (1996): Almonds (Prunus). [In: Moore, J. N., Janick, J. (eds.), Fruit Breeding] Wiley \& Sons, New York, pp. 1-97.

Kodad, O., Sánchez, A., Saibo, N., Oliveira, M. \& Socias i Company, R. (2008): Identification and characterization of new $S$-alleles associated with self-incompatibility in almond. Plant Breeding, 127: 632-638.

López, M. Vargas, FJ. \& Batlle, I. (2006): Self (in)compatibility almond genotypes: a review. Euphytica, 150: 1-16.

Martínez-Gómez, P., Sánchez-Pérez, R., Dicenta, F., Howad, W., Arús, P. \& Gradziel, T. (2007): Almond. [In: Kole, C. (ed.), Fruits and Nuts], Vol. 4. Springer, Berlin Heidelberg, pp. 229-242.

McClure, B. A., Haring, V., Ebert, P. R., Anderson, M. A., Simpson, R. J., Sakiyama, F. \& Clarke, A. E. (1989): Style selfincompatibility gene products of Nicotiana alata are ribonucleases. Nature, 342: 955-957. 
Ortega, E., Boskovic, R. I., Sargent, D. J. \& Tobutt, K. R. (2006): Analysis of S-RNase alleles of almond (Prunus dulcis): characterization of new sequences, resolution of synonyms and evidence of intragenic recombination. Mol. Genet. Genom., 276: 413-426.

Ortega, E., Sutherland, B. G., Dicenta, F., Boskovic, R. \& Tobutt, K. R. (2005): Determination of incompatibility genotypes in almond using first and second intron consensus primers: detection of new $S$-alleles and correlation of reported $S$ genotypes. Plant Breeding, 124: 188-196.

Sonneveld, T., Tobutt, K.R. \& Robbins, T.P. (2003): Allelespecific PCR detection of sweet cherry self-incompatibility $(S)$ alleles $S 1$ to $S 16$ using consensus and allele-specific primers. Theor. Appl. Genet., 107: 1059-1070.

Sutherland, B.G., Robbins, T.P. \& Tobutt, K. R. (2004): Primers amplifying a range of Prunus $S$-alleles. Plant Breeding, 123: 582584.

Szikriszt, B., Hegedüs, A. \& Halász, J. (2011): Review of genetic diversity studies in almond (Prunus dulcis). Acta Agron. Hung., 59: 379-395.

Thompson, J. D., Higgins, D.G. \& Gibson T.J. (1994): CLUSTAL $\mathrm{W}$ : improving the sensitivity of progressive multiple sequence alignment through sequence weighting, positions-specific gap penalties and weight matrix choise. Nucleis Acid Res. 22: 4673-4680. 